\title{
MLTI EDUCATION IN CHINA: CURRENT SITUATION, CHALLENGES AND COUNTERMEASURES
}

\author{
Qinglin MA ${ }^{1}$, Prof. PhD \\ Xin FU, PhD \\ Northwest University of Political Science and Law \\ School of Foreign Languages \\ Xi'an, Shaanxi, P.R. China \\ horserman@163.com \\ fuxinadr@163.com
}

\begin{abstract}
Based on the Guideline for MTI Training Program established by China National Committee for MTI (Master of Translation and Interpreting) Education, this research makes a successive survey on the status quo of master education of legal translators and interpreters from 2014-2016 to trace the changes and problems revealed in the five major universities of political science and law in China. By comparing and analyzing the information and facts collected on the training target, curriculum setting, teaching staff, platform construction, practical training as well as the employment in those five universities, the authors sort
\end{abstract}

${ }^{1}$ Dean, School of Foreign Languages, Northwest University of Political Science and Law. 
out the diversified advantages and features of the five law schools, and probe into the existing problems and difficulties in common. On the grounds of the survey and interview conducted by the authors in the recent years, the authors put forward the solutions and suggestions on the improvement and future development of Chinese MTI education.

Key words: Master of Legal Translation, education, current situation, challenges, countermeasures

\title{
中国法律翻译硕士教育：现状、挑战与对策
}

\begin{abstract}
摘要: 本研究以培养中国的高层次、复合型、创新型和应用型法律翻译 为其人才培养目标。它立足于全国MTI教育指导委员会制定的《翻译硕 士培养计划》为指导方针, 并以中国五所政法大学的法律翻译硕士课程 为研究对象。本文通过对2015-2016 年调研收集的数据和文献进行比较 分析, 对培训目标、课程设置、师资队伍、平台建设、实践培训以及学 生就业等方面的现状进行了研究, 梳理了各高校的课程优势, 并指出了 存在的共性问题。此外, 还提出了进一步完善我国 MLTI 人才培养的 对策和建议。
\end{abstract}

关键词：法律翻译硕士, 教育, 现状, 挑战, 对策

\section{KSZTAŁCENIE TŁUMACZY USTNYCH I PISEMNYCH W CHINACH: STAN OBECNY, WYZWANIA I ROZWIĄZANIA}

\begin{abstract}
Abstrakt: Autorzy, w oparciu o Przewodnik Programu Kształcenia Tłumaczy Pisemnych i Ustnych ogłoszony przez Chiński Państwowy Komitet Kształcenia Tłumaczy Pisemnych i Ustnych, badają status studiów magisterskich w Chinach w zakresie kształcenia tłumaczy prawniczych w latach 2014-2016. Celem jest wychwycenie zmian i problemów, jakie zaistniały $\mathrm{w}$ ramach przedmiotu badania na pięciu największych chińskich uniwersytetach. Analizie poddano informacje i dane rzeczywiste zgromadzone na zajęciach kursowych a zawarte w programach studiów, dotyczące kadry, struktury platformy, zajęć praktycznych oraz informacje dotyczące zatrudnienia w badanych uniwersytetach. Autorzy artykułu skategoryzowali ww. informacje według zalet i charakterystyki określonych pięciu wydziałów prawa i podjęli próbę zdefiniowania ich wspólnych problemów. W oparciu o przeprowadzone badania autorzy artykułu wskazują określone sugestie, możliwości rozwiązania danych problemów oraz potencjalne ulepszenia, które sprzyjać będą przyszłemu rozwojowi kształcenia tłumaczy prawnych w Chinach.
\end{abstract}


Słowa-klucze: studia magisterskie $\mathrm{w}$ zakresie przekładu prawniczego, edukacja, obecny stan, wyzwania, środki zaradcze.

\section{Introduction}

Although still at its infant stage, the Chinese Master of Translation and Interpreting (hereafter referred to as MTI), ${ }^{2}$ however, is a fledging and promising program in China. It aims at fostering translation/ interpretation talents to meet the demand of adapting the globalized economy, enhancing national competitiveness at the international level and cultivating high-quality, practical and professional translators and interpreters for the national construction in the economic, cultural and social fields. With the promulgation of the MTI program, the Ministry of Education of the People's Republic of China ratified 15 MTI pilot training universities nationwide in 2007 and Beijing International Studies University and other 24 universities in 2009 respectively ( $21^{\text {st }}$ Century 2009). In 2011, the number of the training institutions has risen to 159 (China National Committee for MTI Education 2014). By the end of 2014, 206 universities and colleges have obtained the qualifications of running the MTI programs, and the number of enrolled MTI candidates has reached 20,257 in total in China (Tian, Sun and Rong 2014: 233; Zhong 2014: 40-44). By the end of 2016, there had been 215 universities and colleges that were qualified to enroll the candidates for the MTI Program. ${ }^{3}$ According to the authors' latest

${ }^{2}$ In fact, the history of the MTI program can be traced back to January 2007, when the Academic Degree Program for Master of Translation and Interpreting was deliberated and adopted on the $23^{\text {rd }}$ Session Conference of the Office of the State Council Academic Degrees Committee in China. It stipulates, "Master of Translation and Interpreting is established for the purpose of cultivating high-level, practical advanced translation and interpreting talents in order to meet the needs of our country's Opening Policy, construct the socialist modernization and advance the international exchange." Details are available at http://www.cdgdc.edu.cn/xwyyjsjyxx /gjjl/szfa/fyss/263550.shtml (Accessed on 16 October 2016).

See the speech given by Professor Zhao Junfeng, Secretary-General of the China National Committee for MTI Education in a survey activity 
investigation in early 2018, 249 universities and colleges are qualified for enrolling the MTI candidates nationwide.

The latest official Guidelines for MTI Training Program (hereinafter referred to as the "MTI Guidelines") was revised by China National Committee for MTI Education in 2010 and after the continuous development in recent years, the MTI education in China has made outstanding achievements in many fields. In the meanwhile, the training universities weighed their special characteristics and advantages in majors, actively explored various talent cultivation modes, mostly, one advantageous major + translation, such as the "technology + translation", "engineering + translation", "petroleum technology + translation", "medical science + translation" and so on, and accumulated abundant successful experience in this regard.

Among these approved training universities, Chinese universities of political science and law have formed a specialized school of "law + translation" mode. As early as 2010, Southwest University of Political Science and Law and Zhongnan University of Economics and Law obtained the qualifications, while China University of Political Science and Law, East China University of Political Science and Law, and Northwest University of Political Science and Law possessed such qualifications in 2014 respectively. These institutions incorporate their special advantages such as the long history of the researches on law science into the MTI Program. Given that these five universities of political science and law were directly affiliated to the Ministry of Justice in China and shared a unique MTI cultivation mode - "Law + Translation".

This paper takes the five universities of political science and law in China as its research object. As a descriptive research of MTI education in China, the authors intend to adopt both conceptual and empirical research method. In the paper, the authors first introduce and define a series of basic concepts on Chinese MTI education. Then, the overall theoretical framework of the research is interpreted and the results of the analysis of the investigations and interviews are presented. With the analyses of the surveys and interviews, the authors then describe the phenomena of existing status of Chinese MTI education. Then on the basis of the collected

conducted in Henan and Shandong in December 2016 regarding the MTI education and the students' employment. 
data and related analysis, the explanations and generalizations are presented in detail.

To be specific, the authors have sorted out some program advantages and features shared by the five universities through comparing and analyzing the data and literatures collected in the survey during 2015-2016 on the status quo related to the training target, curriculum setting, teaching staff, platform construction, practical training as well as employment. The authors attempt to probe into the existing problems in common, and puts forward some countermeasures and suggestions on further improvement in the cultivation of MLTI talents.

\section{Goals of MTI Education and Its Curriculum}

The Assessment System of MTI Teaching established by China National Committee for MTL Education includes 6 items of first-level indexes, 20 items of second-level indexes, and 47 items of major observation points (China National Committee for MTI Education 2013). It set the goal setting and curriculum design in the notion and content of the teaching, two of the six first-level indexes, a substantively significant position. Such assessment system provides the MTI Program a clear and systematic evaluation on disciplinary construction and teaching of the translation/interpretation in China (Secretariat of China National Committee for MTI Education 2012: 52-56). Accordingly, this paper mainly discusses the goal setting and curriculum design of the five universities of political science and law in this section.

As far as the goals of MTI programs in the five law universities, they differ in a varying degree. For example, Zhongnan University of Economics and Law set the goal of MTI program as "cultivating high-level, practical and professional translation talents of law and business". Southwest University of Political Science and Law clarifies its goal of the program as "cultivating practical

4 See also the Self-Assessment Report of MTI Education, Zhongnan University of Economics and Law (2015), Conference materials of International Academic Forum on MTI Education, in Northwest University of Political Science and Law, Xian, June 2016. 
and professional translation talents of law and dedicating to cultivation of the students' capability in legal translation and enhance their professionalism". Likewise, China University of Political Science and Law states its goal as "cultivating advanced legal translators and interpreters who know well in both China and the Western countries, and are competitive in both law and translation and adapt themselves to the needs of national social, economic, cultural and rule-of-law construction". 6 East China University of Political Science and Law describes its goal of MTI program as "cultivating high-level, practical, and professional legal translators who can meet the needs of China's social and cultural development and construction of legal system and are qualified for China's social, economic and cultural development. ${ }^{7}$ Northwest University of Political Science and Law sets its goal of MTI program as "taking legal translation as its characteristic MTI educational orientation, cultivating high-level, practical and professional translators who have international vision, innovative capability and critical thinking skills." 8

From the descriptions mentioned above, it can be easily found that all the five universities have coincidently emphasized "high-level, practical and professional" quality in the training of translator/interpreters and specified their marketing positions of "meeting the needs of the state's social, economic, cultural and rule-of-law construction". What's more important, all the MTI training universities are endeavoring to integrate their advantageous majors and disciplines, along with their characteristic BA program of legal English major, into the MTI program. The goals of all the five

5 See also the Self-Assessment Report of MTI Education, Southwest University of Political Science and Law (2015), Conference materials of International Academic Forum on MTI Education, in Northwest University of Political Science and Law, Xian, June 2016.

${ }^{6}$ The MTI Program of China University of Political Science and Law (2015), Conference materials of International Academic Forum on MTI Education, in Northwest University of Political Science and Law, Xian, June 2016.

${ }^{7}$ The MTI Program of East China University of Political Science and Law (2015), Conference materials of International Academic Forum on MTI Education, in Northwest University of Political Science and Law, Xian, June 2016.

${ }^{8}$ The MTI Program of Northwest University of Political Science and Law (2015). 
universities primarily formed the common feature - Master of Legal Translation and Interpreting (MLTI). Moreover, some of the five universities, such as Zhongnan University of Political Science and Law and Southwest University of Political Science and Law even added some commerce and business elements into its MLTI Program.

As for the curriculum setting, the five MLTI universities (except for East China University of Political Science and Law) divide their course systems into three categories, namely, common compulsory courses, compulsory MTI courses, and optional MTI courses. The MLTI candidates are required to earn 38 credits in order to reach partial requirement of graduation, which is the least requirement of the MTI Guidelines. Regarding the length of schooling, Northwest University of Political Science and Law sets its training program to 3 years, which if necessary can be extended up to 5 years, while the other four sample universities adopt a 2-year training program, which can be extended up to 3-4 years. Furthermore, with regard to the specific content of the common compulsory courses and compulsory MTI courses, all the universities stress the training of basic language skills, linguistic and cultural knowledge, translation theories, and practical translation abilities, which also meets the requirement of the MTI Guidelines. As far as the content of optional MTI courses is concerned, however, there are conspicuous divergences between the five universities, which can be justified by the differences of the geographical locations of the universities or the difference of the educational background of the MTI candidates.

Table 1: Options courses for MLTI Candidates at the of the Five Universities of Political Science and Law in China

\begin{tabular}{llrl}
\hline $\begin{array}{l}\text { Name of } \\
\text { the } \\
\text { Institution }\end{array}$ & Basic law courses & Legal translation courses \\
\hline & $\begin{array}{l}\text { Theory of the Law; } \\
\text { Introduction to the }\end{array}$ & $\begin{array}{l}\text { Translation of Legal Texts; } \\
\text { Translation of Laws and }\end{array}$ \\
SWUPL & $\begin{array}{l}\text { Contract } \\
\text { Comparative Study of }\end{array}$ & $\begin{array}{l}\text { Regulations; Translation of } \\
\text { English-Chinese Contracts; } \\
\text { Legal Cultures between } \\
\text { China and the West }\end{array}$ & $\begin{array}{l}\text { Translation of Legal Terms } \\
\end{array}$ \\
\hline
\end{tabular}


Qinglin MA, Xin FU: MLTI Education in China...

\begin{tabular}{|c|c|c|}
\hline ZUEL & $\begin{array}{l}\text { Comparative Study of Law } \\
\text { and Business Culture } \\
\text { between China and the } \\
\text { West }\end{array}$ & $\begin{array}{lrr}\text { Practical } & \text { Training of } \\
\text { Contract Translation; Legal } \\
\text { Document } & \text { Translation; } \\
\text { Translation of Laws and } \\
\text { Regulations }\end{array}$ \\
\hline CUPL & $\begin{array}{l}\text { Anglo-American Legal } \\
\text { System (Bilingual); } \\
\text { Reading and Translation of } \\
\text { Legal Cases }\end{array}$ & $\begin{array}{lcc}\text { Translation } & \text { of Legal } \\
\text { Documents; } & \text { Translation of } \\
\text { Contracts; } & \text { Translation of } \\
\text { Legal Terms } & & \\
\end{array}$ \\
\hline ECUPL & $\begin{array}{l}\text { Theory of the Anglo- } \\
\text { American Law }\end{array}$ & $\begin{array}{l}\text { Translation of Laws and } \\
\text { Regulations; Translation of } \\
\text { Contracts }\end{array}$ \\
\hline NWUPL & $\begin{array}{l}\text { Introduction to } \\
\text { Fundamental Theory of the } \\
\text { Law; Intellectual Property } \\
\text { Law; Introduction to Civil } \\
\text { and Commercial Law; } \\
\text { Procedural Law. }\end{array}$ & $\begin{array}{l}\text { Translation of Legal } \\
\text { Documents; Translation of } \\
\text { Laws and Regulations; } \\
\text { Translation of Intellectual } \\
\text { Property }\end{array}$ \\
\hline
\end{tabular}

First, the five law universities have different arrangements of law courses in the MLTI Programs. For instance, East China University of Political Science and Law offers one law course Theory of the Anglo-American Law. Similarly, Zhongnan University of Economics and Law offers one course entitled "Comparative Study of Law and Business Culture between China and the West", which does not only include the "business" element, but also offers a perspective of culture between China and the Western countries. China University of Political Science and Law offers two law courses for the students - "Anglo-American Legal System (Bilingual)" and "Reading and Translation of Legal Cases". Comparative speaking, Southwest University of Political Science and Law offers students more choices (three law courses) in this respect - "Theory of the Law", "Introduction to the Contract Law", and "Comparative Study of Legal Cultures between China and the West". However, the law course in the MLTI Program offered by Northwest University of Political Science and Law is the most in number: four optional law courses, including "Introduction to Fundamental Theory of the Law", "Intellectual Property Law", "Introduction to Civil and Commercial Law", and "the Procedural Law". It is probably because at the time of designing the curriculum, it assumes that most MLTI candidates lacked of necessary law knowledge before admission to the program. 
Second, as for the optional MLTI courses, the five universities have reached a common understanding in this regard. For example, Zhongnan University of Political Economics and Law offered such courses as the "Practical Training of Contract Translation", "Legal Document Translation" and "Translation of Laws and Regulations". Southwest University of Political Science and Law offered the "Translation of Legal Texts", "Translation of Laws and Regulations", "Translation of English-Chinese Contracts" and "Translation of Legal Terms". East China University of Political Science and Law offered such courses as "Translation of Laws and Regulations" and "Translation of Contracts". China University of Political Science and Law provided the candidates with three such courses: "Translation of Legal Documents", "Translation of Contracts" and "Translation of Legal Terms". Northwest University of Political Science and Law divides its Translation of Legal Texts into three sections: "Translation of Legal Documents", "Translation of Laws and Regulations" and "Translation of Intellectual Property".

It can be seen that all the five universities have considered major categories of the legal translation - legal documents, laws and regulations, legal texts and contracts. ${ }^{9}$ It is also noticeable that, China University of Political Science and Law and Southwest University of Political Science and Law have offered a course "Translation of Legal Terms". Likewise, Zhongnan University of Economics and Law, Southwest University of Political Science and Law and East China University of Political Science and Law have added a course "Translation of Commercial Documents" into their respective curriculum. Moreover, considering the translation needs of the market regarding China's innovation capability and international patents application, Northwest University of Political Science and Law uniquely offers a course "Translation of Intellectual Property" in its curriculum.

\footnotetext{
${ }^{9}$ Northwest University of Political Science and Law incorporates "contract" into the category of "legal texts".
} 


\section{Current Situation on the Development of the Teaching Staff}

The teaching quality of the training institutions and the extent of the candidates in mastering professional skills are, in a certain degree, closely related to the experience and skills of the teachers. In order to conduct well the MTI education, and guarantee quality of the education, five training institutions are equipped with the best teaching resources. For example, Southwest University of Political Science and Law mainly relied on its team of legal translation research, which includes 18 full-time faculty staff of the MTI program. Among them, $94.44 \%$ are professors or associate professors, $83.33 \%$ are holders of a master's degree, $100 \%$ have had the translation/interpretation experience, and one full-time faculty staff can offer 1-2 specialized MTI degree courses on average. ${ }^{10}$

Zhongnan University of Economics and Law sticks to the principle of combining full-time and part-time staff, planning and the demand of the teaching staff, import and self-trained staff, and studying abroad and at home. There are 27 name full-time teachers in the MTI Education Center, 10 of them focus on the teaching of interpretation while the other 17 on the translation. All the teaching staff possessed a master degree or above, among which 15 had a doctoral degree. The Center's staff includes 6 professors and 12 associate professors (accounted for $66.7 \%$ of the teaching staff); $85.2 \%$ have the experience of overseas study or visit. Moreover, 10 staff has possessed the multi-disciplinary background, accounted for $37.03 \%$; and each teacher can offer more than two MTI specialized courses. ${ }^{11}$

${ }^{10}$ See Self-Assessment Report of MTI Education, Southwest University of Political Science and Law (2015), Conference materials of International Academic Forum on MTI Education, in Northwest University of Political Science and Law, Xian, June 2016.

11 See Self-Assessment Report of MTI Education, Zhongnan University of Economics and Law (2015), Conference materials of International Academic Forum on MTI Education, in Northwest University of Political Science and Law, Xian, June 2016. 
Table 2: Statistics on the Teaching Staff of the Five Universities of Political Science and Law in China.

\begin{tabular}{lllllllll}
\hline $\begin{array}{l}\text { Name of } \\
\text { the } \\
\text { Institution }\end{array}$ & $\begin{array}{l}\text { No. of full- } \\
\text { time } \\
\text { teaching } \\
\text { staff }\end{array}$ & $\begin{array}{l}\text { Degree held by } \\
\text { the teaching staff }\end{array}$ & $\begin{array}{l}\text { Academic rank of the } \\
\text { teaching staff }\end{array}$ \\
\hline & & PhD & MA & BA & Prof & AP & Lect & TA \\
\hline SWUPL & 18 & 8 & 7 & 3 & 9 & 8 & 1 & 0 \\
ZUEL & 27 & 15 & 12 & 0 & 6 & 12 & 9 & 0 \\
CUPL & 16 & 12 & 4 & 0 & 7 & 6 & 2 & 1 \\
ECUPL & 14 & 13 & 0 & 1 & 5 & 6 & 3 & 0 \\
NWUPL & 16 & 3 & 13 & 0 & 5 & 7 & 2 & 2 \\
\hline
\end{tabular}

Note: $P h D=P h . D . M A=$ Master $B A=$ Bachelor Prof=Professor AP=Associate professor Lect=Lecturer TA=Teaching assistant

East China University of Political Science and Law currently has employed 14 MTI supervisors, including 13 holders of doctoral degree, and around $55 \%$ of them have the background of linguistics/translation and law, and majority of the supervisors had the experience of overseas exchange. Moreover, its student-teacher ratio is $2.5: 1$ on the base of 35 MTI candidates, which is far below than that in other majors. ${ }^{12}$

Northwest University of Political Science and Law possesses 14 specialized instructors, 10 of them are selected supervisors with the title of associate professors or above, and the remaining four teachers either have doctorate degrees or are $\mathrm{PhD}$ candidates. ${ }^{13}$

In China University of Political Science and Law, among the 16 full-time MTI staff, there are 7 professors, 6 associate professors, 2 lecturers, and 1 teaching assistant, and all of them had a master's degree, including 12 holders of doctoral degree (75\%).

Our research found that a considerable part of the specialized supervisors or teachers at the five training universities were

${ }^{12}$ The MTI Program of East China University of Political Science and Law (2015), Conference materials of International Academic Forum on MTI Education, in Northwest University of Political Science and Law, Xian, June 2016.

${ }^{13}$ The MTI Program of Northwest University of Political Science and Law (2015), 4 September 2015, available at http://fli.nwupl.cn/Item.aspx?id=3755 (Accessed 17 October 2016). 
transferred from the team of academic tutors, and some of them are undertaking a dual task of being both academic supervisors and professional mentors. Selection of the MTI Program supervisors has to go through a procedure, that is, the university's academic committee will review and approve the supervisor or teaching candidates recommended by the school in charge upon personal application. In addition, the training universities identified a group of back-up force through the MTI platform, e.g. those who have extensive experience in translation or lecturers with doctoral degrees, who will undertake the teaching task at first and then can be selected as the supervisor when necessary and qualified.

\section{Practice, Training and Employment of the MTI Candidates}

Practice and training are two important components in the MTI education, which are significant to the MTI candidates in consolidating, deepening and expanding their theoretical knowledge and professional skills, fostering their innovative and enterprising spirits and making a rational career planning. In this research, we only focus on the candidates of the Southwest University of Political Science and Law and Zhongnan University of Economics and Law as the target as the two universities started their MTI programs in 2011 and have had MTI graduates in three successive years.

Southwest University of Political Science and Law paid much attention to the translation practice, emphasizing cultivation of the translation skills and case analysis in translation through the whole process of its program. It requires the MTI candidates at school to complete a compulsory workload of legal translation of 150,000 Chinese characters. To guarantee the implementation of such practice, the University adopts a dual tutorial system. It offers a 3-credit translation practice course in the curriculum, requiring the candidate to engage in such translation practice during the first three semesters in the form of group and separate internship. As a rule, the total period of internship is no less than 6 months while the group internship is no less than 3 months. After the practice, the MTI candidates are required to submit a field research report of 6,000 Chinese 
characters. Moreover, the University cooperated with Chongqing Living Translation Company and Chongqing Holiday International Travel Service to build the long-term translation practice bases with the capacity of accepting 30 MTI candidates at one time.

Zhongnan University of Economics and Law requires its MTI translation candidates at school to complete the task of legal translation of 150,000 Chinese characters, while the MTI interpreting candidates have to finish the practice of 400 tape hours. It divides candidates' translation/interpretation practice into four essential stages - In-classroom practice, professional practice, report of the achievements in practice, and dissertation. There is a strict evaluation standard in each of the evaluation process. If a candidate cannot reach the standard, he or she would not have an opportunity to enter into the practice and study at the next stage. In the aspect of practice bases, the University has founded six practice and training bases cooperating with such units as Transn Information Technology Company (Wuhan), Hubei Education and Technology Publishing House, and Lankam Business Solution Co. Ltd (Shanghai). All the training bases can guarantee at least five training positions each year. During 2013-2015, more than 60 MTI candidates participated in such practice as translation of the monetary, financial and commercial documents, journal and news editing and translation, interpretation of exhibition events, lectures and conferences liaison. Moreover, the University established an on-campus practicing platform, such as Yi Dao (Skills of the Translation), a journal founded in 2013, which offers such translation columns as the commercial and legal translation, and translation skills. The MTI candidates at Zhongnan University of Economics and Law also undertake the work of translating publicity materials for "China Monetary and Financial History Museum" and offer English tour guide for the Museum.

Employment of the MTI candidates at the two universities is rather satisfactory. According to the statistics, ${ }^{14}$ Southwest University of Political Science and Law enrolled 20 students in 2011, 30 students in 2012 and 36 students in 2013 respectively. In addition,

${ }^{14}$ Presentation by the representative of the Southwest University of Political Science and Law (2015), Conference materials of International Academic Forum on MTI Education, in Northwest University of Political Science and Law, Xian, June 2016. 
the employment rate of the 2011 graduates is $100 \%$ : nine worked in educational institutions (45\%), 6 in enterprises (30\%), 3 in law firms and consulting companies (15\%) and 2 in governmental agencies $(10 \%)$. In $2014,96.7 \%$ of the graduates were employed in various units, ${ }^{15}$ including eight in the educational institutions (28\%), $17 \%$ lower than that in 2011; 11 in enterprises (38\%) $-8 \%$ higher than that in $2011 ; 5$ in law firms $(17 \%)-2 \%$ higher than that in 2011; 3 in financial services and banking agencies (10\%); and one in judicial department (3\%).

Chart 1: Employment statistics of the graduates of Year 2011 and Year 2012 of Southwest University of Political Science and Law.
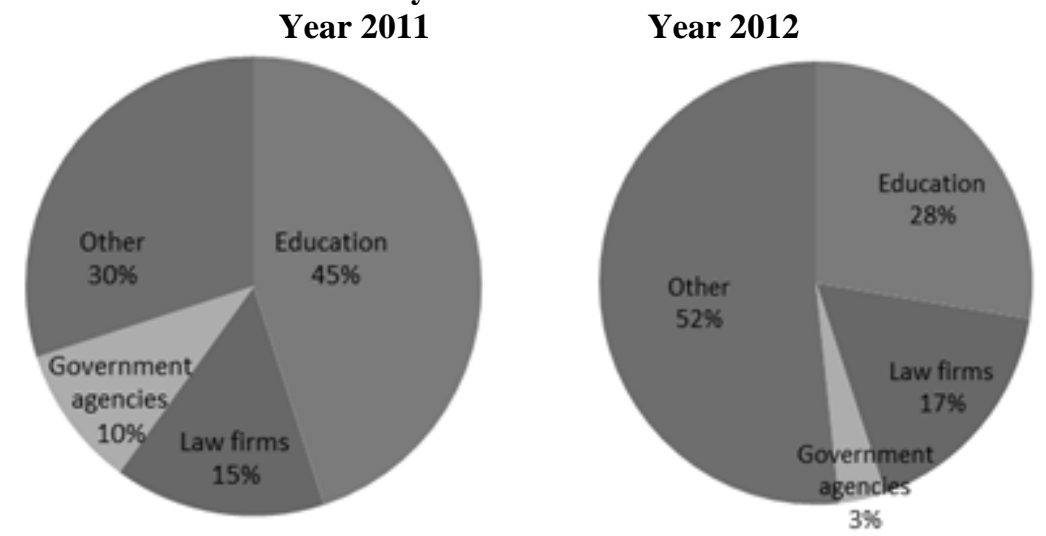

Chart 2: Employment statistics of the graduates of Year 2011 and Year 2012 of Zhongnan University of Economics and Law.
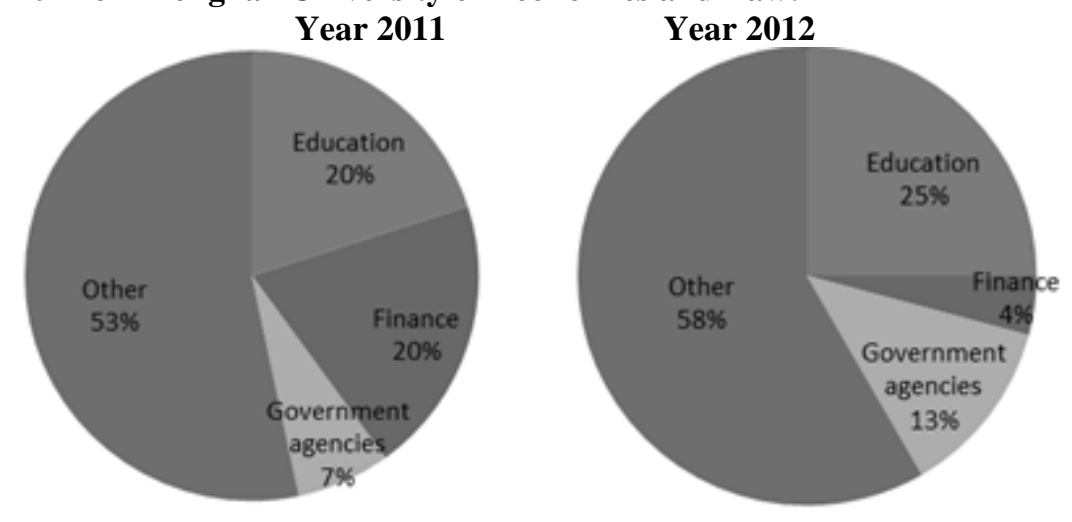

\footnotetext{
${ }^{15}$ Here, one graduate was unemployed in Year 2014.
} 
Similarly, Zhongnan University of Economics and Law enrolled 15 candidates in 2011, 24 in 2012, and 26 students in 2013. From 2013 to 2015, the employment rate of MTI candidates in the University was $100 \%$. According to the statistics, the employment rate of 2011 graduates was $100 \%$ : three out of the 15 graduates worked in the higher education institutions (20\%), 8 in enterprises (53\%), 3 in financial institutions (20\%), and 1 in the governmental agency (7\%). Likewise, among the graduates in 2014, 6 out of 24 entered into educational institutions (25\%) in 2014, 14 in enterprises and institutions (58\%), 1 in a financial institution (4\%), 3 in governmental agencies $(12.5 \%){ }^{17}$.

\section{Current Problems in the MLTI Education}

Currently, the MLTI education has encountered similar problems as those in the MTI education, among which some problems are common and some are of special feature. First, the goals of MTI and Master of Translation (Academic Direction) are not clear enough. Although fostering the candidates of MTI and other traditional academic programs shares something in common - for example, they both require solid bilingual and literary backgrounds and some

${ }^{16}$ Including 5, 6 and 8 candidates in the translation direction and 10, 18 and 18 candidates in the interpreting direction in 2011, 2012 and 2013 in turn. Among them, around $80 \%$ of the MTI candidates came from its own university, Southeast University, Huazhong Normal University, Jiangxi University of Finance and Economics and other key universities.

17 The MTI candidates were employed in many renowned enterprises and institutions, such as Foreign Affairs Office of Hubei Provincial People's Government, Shanghai Sports Bureau, Huaiyin State Revenue Bureau of Jinan City, China Merchants Bank, Bank of Communications, Guangxi Normal University, Wuhan Textile University, China Railway Construction Engineering Group Co., Ltd., China Wuhuan Engineering Co., Ltd., Hainan Airlines Co., Ltd. Among them, $76.9 \%$ of the University's MTI graduates took a job related to language and translation services. See also the SelfAssessment Report of MTI Education, Zhongnan University of Economics and Law (2015), Conference materials of International Academic Forum on MTI Education, in Northwest University of Political Science and Law, Xian, June 2016. 
theoretical basis, most training universities paid inadequate attention to the practical side of the MTI program in practice because there are more courses on theories but less on practices. This in fact has betrayed the original purpose of running the program. According to the philosophy of cultivating modern professional masters' candidates, the MTI should undertake the responsibilities of cultivating high-level, practical and professional translation talents, because it could not replace the traditional academic program of master in translation.

"In those economically developed countries, except for a small number (who are in the preparation for the doctoral study), the master's candidates should be high-level professional talents in all walks of life, while the doctoral education is mainly for fostering teaching staff of higher education and researchers of scientific researches" (Bao 2003: 48-50). With the increase of the exchange of international trade and technology, inter-disciplinary talents of English-Chinese and Chinese-English translation are in urgent need in the human resource market. Domestic translation industry needs more masters of translation who grasp theoretical knowledge (not theoretical research) and have a good command of practical legal translation. Under such circumstances, the studies on the teaching of legal translation/interpretation were launched in the Chinese universities. However, such study of the teaching is still in the grey area of translation studies, which cannot supply high-quality talents for the international and domestic markets (Cao, Han and Liu 2015:105-108). Therefore, talents supply of the teaching of legal translation/interpretation needs further improvement in order to keep up with the market demand.

Second, the construction of team of teaching staff is imbalanced, and the number of practical teachers is in great shortage in China (Xu 2017:14-20). ${ }^{18}$ The teaching of professional postgraduate degree requires teachers to possess the capability of translation practice, teaching and research, but some training universities have not completely reached the requirement in staffing yet. ${ }^{19}$ Few teaching staff can use such important tools as the Trados

\footnotetext{
${ }^{18}$ In this regard, see Shan's survey in northeastern China (2016:2-7).

19 For detailed discussions, see also Wang Jun and Yu Jiayi, "Problems and Countermeasures in the MTI Education", (2016) Modern Communication (Xiandai Jiaoji) (426)4:226-227.
} 
in the teaching of translation in certain number of Chinese universities. On the other hand, the MTI Guidelines stipulated a relatively high requirement on teaching staff: The core and important compulsory courses need involvement of at least two experienced but full-time teachers. Among the teaching staff, no less than $70 \%$ should have the experience of translation and interpretation; the translation teachers should have the experience of completing the translation work of more than 300,000 Chinese characters and the interpretation teachers should have the experience of undertaking formal consecutive and simultaneous interpretations for more than 20 times.

In addition, the Guidelines also required certain number of part-time teachers who are senior translators coming from the translation practice institutions. However, the problem is that, "academic research" and "practical skills" are deviated in China's translation circle and the disputes between "theory" and "skill" have lasted for a long time. Overemphasis of "academic" and the underestimation of "practical skills" happen in various aspects in institutions of higher education, such as academic promotion, application of research projects, and achievement award. ${ }^{20}$ Accordingly, teachers at the universities and colleges just care about theoretical researches on translation and neglect the translation practice, as "People usually have little praise and encouragement for translation" (He 2007:24-29). Inadequate lack of practical teachers, especially teachers for the interpretation class, brings about only in small number but also low quality.

Third, there is no guarantee on the source of excellent candidates in running the program. At present, public recognition of the MTI Program is not very high, which needs improving, and accordingly the program cannot attract the enthusiasm of excellent candidates at the enrollment stage. The competent department of the Ministry of Education has changed the enrollment policy on the MTI program, which allowed applicants for the academic masters' degree who have reached the admission line in the National Graduate Admission Examination to be transferred to the MTI Program, and such a policy may increase the number of MTI applicants and attract some excellent applicants.

${ }^{20}$ In our opinion, even in the MTI program, there is a need to make a balance between the academic and practical perspectives. 
However, such a phenomenon also reflected the fact that the enrollment is not so ideal: The institutions need loosen the admission requirement in order to finish the task of its enrollment (Kong and Wang 2011:9-15).

According to the survey during 2014 and 2015, the personsin-charge of the MTI programs at the five universities of political science and law all expressed that under the situation that few highscore candidates actively applied for the MTI Program, those applicants sifted out from the academic master program with lower scores could also be admitted to the Program. ${ }^{21}$ Moreover, mostly, they were from the second level or third level universities. Although some applicants' scores of National Graduate Admission Examination are qualified, many of them are not in English major who have not received systematic linguistic training and well-grounded language education. Consequently, their language skills are not proficient enough and their translation experience is deficient, without any translation training. Moreover, judging from the applicants' intention to take the MTI program, some of them would obtain a degree in a shorter term ( 2 years) instead of the study interests or career design. In addition, the national policies on MTI education are not so well developed, thus they cannot stimulate the applicants' motives in the application for the Program. ${ }^{22}$

Fourth, the disintegration between the practice and training bases and students' practical skills continues to exist in China. The MTI Guidelines clearly required to the Programing institutions to establish practicing and training bases, but according to the survey, some training universities apparently need more vacant practice positions for students, namely, a practice and training base that

21 In addition, the percentage of non-English major MTI candidates is gradually increasing year by year, which also brought challenges in the teaching, as the teaching staff needs to tailor the candidates' special situation, for example, more efforts in making up their English background. For detailed discussions, see Wang and Yu 2016: 226-227.

22 In order to attract more excellent applicants, Zhongnan University of Economics and Law launched a student summer camp - "Star of Humanities" and East China University of Political Science and Law started the first "Legal Translation Summer Camp" in 2016 for the same purpose. See the Conference materials of International Academic Forum on MTI Education, in Northwest University of Political Science and Law, Xian, June 2016. 
can provide more than five positions. The situation of having such suitable practicing and training bases for the MLTI Program is even more challenging. In the translation practice, for example, the quality and quantity of MLTI candidates' translation is problematic, which may lead to the ineffective operation of the training bases. ${ }^{23}$ As for the practice of interpretation, it is more difficult for the candidates to practice their skills because the formal conferences are required to equip with more experienced professional interpreters. $^{24}$ The result is that, the MTI candidates can just be the "service personnel" of the international events. Again, one quick solution is to arrange some international hotels and travel agencies for MTI candidates' practice training, but the connection between the practice and legal translation seems to be far-fetched. ${ }^{25}$

\section{Solutions and Suggestions for the Development of MLTI Program at the Universities of Political Science and Law}

Based on the problems discussed in the previous sections, we can propose the following four suggestions, which may contribute to the development of the MLTI Program in the future.

\footnotetext{
${ }^{23}$ This is actually in a dilemma: The future employers hope to accept some potential candidates who have some fundamental knowledge to practice in their institutes, as they do not have sufficient staff to train and teach the practical skills of translation/interpretation; while the candidates are often not well prepared in practice, who want to learn through the practice.

${ }^{24}$ See also the interviews with some practitioners, conducted by the author in a survey in 2014-2015 in Beijing, Xian, Shenzhen and Guangzhou.

${ }^{25}$ In a recent survey, Shan Ping also reported the shortage of practice base for the MTI programs in Dalian of Liaoning Provinces. See Shan 2016:4.
} 


\subsection{Projecting the Characteristics of the University and Cultivating the Inter-Disciplinary Translation Talents with Combined Majors of Law and Translation}

A Chinese Professor, Zhong Weihe, points out that, two questions on the philosophy of cultivating translation talents have to be clarified by the training universities in the process of MTI program development: First, how to define the translation talents? Second, how do we cultivate those translation talents? The training universities have to make a reasonable and featured MTI program and curriculum based on their own specific characteristics and situations when carrying out the MTI Guidelines (Zhong 2014:40-44). We agree with such opinion and support the philosophy that the cultivation of qualified translation talents should develop a featured MTI program and reasonable curriculum considering the needs and development of national and regional markets and combining their own advantageous majors and special features. Therefore, the MLTI program should focus on strengthening and training the capability of candidates' professional legal translation and cultivating interdisciplinary talents. The training universities should integrate their own features with the market needs, and establish the interdisciplinary cultivation mode of law and translation, flexibly adjust and improve the MTI program, reasonably set their teaching goals of the MLTI Program and organize the content of teaching legal translation. Moreover, they should continuously optimize a high-level teaching staff, make the multi-disciplinary teaching methods in legal translation, and establish a scientific and efficient assessment mechanism of legal translation teaching.

\subsection{Building a Team of Inter-Disciplinary Teaching Staff and Developing a Competitive Team of Teaching, Research and Practice}

The MTI training universities need to build and continue to improve the translation teaching staff in such aspects as the quantity, age, educational background, and professional quality. The 
interdisciplinary teaching staff does not only require a good command of both Chinese and English, proficient translation skills and law knowledge, but also the experience and capability in translation practice and research. The MTI program has a clear requirement on the teaching staff in the aspects of both translation and interpretation experiences. If a teacher has little experience and practice in the field of teaching, he or she will not instruct the students well. Just like a Chinese saying goes, "to forge iron, one must be strong". If the teacher is inexperienced, it will be impossible to teach students and solve the problems or confusions encountered in the translation/interpretation practice. Therefore, a qualified MTI teacher must possess the capabilities of translation/interpretation practice, teaching and researching. Furthermore, a qualified teacher needs to be grouped together to form a team of having reasonable educational background as well as the clear research interests and capacities. To this end, the exchange and experience sharing in teaching is essential within the training institution and/or with other universities at the local level if considering the budget constraint. ${ }^{26}$ Of course, we can also consider the further collaboration among the five universities of political science and law and make use of the cooperative platform "the Legal League", for example, the annual conference. Each year, one of the five partners can host one conference with same or similar theme regarding the Core MTI courses for discussion and teaching observation, if there are sufficient funding supports in the training of teaching staff. Such kind of experience sharing will definitely contribute to the improvement of teaching quality among the member schools. Moreover, there are other good opportunities to expand such exchanges in the Greater China as well and even in foreign countries

${ }^{26}$ For example, the author's institution Northwest University of Political Science and Law collaborated with Xian International Studies University in jointly offering course. MTI students from the former will attend the class involving application of the Trados in Xian University of International Studies, while the MTI students from the latter will attend the class on legal documents writing in Northwest University of Political Science and Law. This is a practical manner in addressing staff shortage or insufficient expertise. 
such as the USA. ${ }^{27}$ In addition, the training universities should provide a positive environment for teacher's training and system with abundant but flexible training methods for improving the teaching capacity (Zhuang 2007:148).

\subsection{Strengthening the Development of the Featured Clusters of Courses and Stressing the Practice- Orientated Curriculum in the MLTI Program}

The featured MTI education requires a practice-orientated curriculum, diversified fusion of teaching content, and interactive teaching environment (Dai and Wang 2005:12-16). The MTI program needs to increase the proportion of practice teaching and internship and foster candidates' practical capabilities, innovative awareness, and entrepreneurship in order to realize effective integration of the academic research and practical natures. In short, it is always necessary to apply the principle of practice, development and diversity in the MTI education (Wang 2016). Moreover, as far as the MLTI is concerned, it is also important to consider increase the percentage of law-related courses into the program curriculum, given that most candidates are weak in the knowledge of law (Zhao 2018:192).

Therefore, the task-based, case analysis, simulated, projectbased, multimedia and internet-based, and computer-assisted teaching methods should be encouraged to motivate students' interests during the teaching process. ${ }^{28}$ By these means, students can participate in the whole process of translation teaching and take full advantage

${ }^{27}$ Comparatively speaking, the United States has developed a mature and productive educational system in applied translation, featured by the great demand for translators and interpreters, flexibility in the planning of program orientations, diversity in the curriculum design, and systematic researches in related fields. For example, for detailed discussions in this aspect, see Wang (2012:52-60).

${ }^{28}$ Based on the information collected in a national conference on training of translation/interpretation talents in Beijing in late December 2016, some universities have applied the computer-based corpus in marking and commenting students' translation materials. This is a positive trend in reducing the staff's workload as well. 
of teaching resources. By using the newly adopted software such as the Trados, teachers can teach students to learn the computerassisted and make their future work applicable and professional. Last, cultivation of students' self-study capability, especially by the means of web-based self-study, needs improvement during the teaching.

As far as the design of featured MLTI programs offered at the five Chinese universities of political science and law is concerned, they made an active effort and reached a consensus on the design, that is, Translation of Laws and Regulations, Translation of Legal Texts, Translation of Contracts, and Translation of Legal Documents. The key challenge, however, they are facing is that there is no support of other clusters of relevant courses. Therefore, they are in urgent need of developing the clusters of featured courses in the curriculum. In this regard, it is very importance to learn and borrow from others, including the counterparts from overseas.

\subsection{Conforming the Market Needs and Adopting a Way of the Combination of Production, Teaching and Research}

The cultivation of translation talents cannot achieve its goal if neglecting the market demands. At present, the translation industry has a higher requirement which is far beyond the traditional definition of translation and intepretation on the practitioners in the field of language service. The industry requires the practitioners to possess various skills in language capabilities, localizations, project and term management, translation technolgoy and tools, formatting and printing and translation management. According to a survey report, the Translators Association of China in 2015, there is a disconnection between domestic education on translator and actual need of the translation companies, and one proturding aspect in this regard is the shortage of professional translation talents. As a result, it is always a critical problem for us to continiously reflect the way of cultivating high-quality translation talents in the light of the market need. 
We think there are two approaches in solving this problem. First, the translation equipment needs further upgrade to cater for the needs of translation teaching. Based on the current equipment of the language laboratory, the computer-assisted translation teaching method can be used in order to update the teaching content and efficiency. By using the modern technology, web-based translation, translation memory system, term management and localized software, students can increase their competitiveness in future career. Of course, if being affected by the budget shortage, the software used in the teaching in the training universities can be available through cooperation with the software companies in this respect.

Second, the training universities should actively explore a way of combining the production, teaching and research in the MTI program. It is necessary to understand what the market needs regarding the graduates in the translation/interpretation major. China is on the track of rapid development and the translation needs to keep up with the market development. According to Wang Lifei (2016), the demand for the translation from English to Chinese ten years ago is now changing to the demand for the translation from Chinese to English in 2015. In such context, the training universities should understand the real need of the market, and consider diversified modes of cultivating the translation talents, including the cooperation between the university and the enterprise, and the establishment of training bases and the double tutorial system, which invites the elites of the translation industry to provide guidance to the candidates at school.

Moreover, the universities can also make use of their advantages and favorable conditions to solve students' difficulties in practice. For example, Qufu Normal University of Shandong Province and Zhongnan University of Economics and Law have made such noticeable innovations. Qufu Normal University founded a training base on Rizhao Campus, and invited some experienced translators and interpreters to come to the school, while the MTI candidates of Zhongnan University of Economics and Law undertake the translation work and English tour guide of its museum. ${ }^{29}$ Likewise, Northwest University of Political Science and Law is planning

\footnotetext{
29 Information collected from the materials in an academic conference on the teaching of translation/interpretation in Henan in August 2015.
} 
to create a cooperative training base of legal and commercial translation in order to invite the senior experienced translators to school and arrange social practice for 30 program candidates each year. ${ }^{30}$ We believe such efforts will contribute to achieve the goal of satisfying the market need on one side, and of combing the production, teaching and research perspectives.

\section{Conclusions}

Along with the exchange with international communities, China needs more talents in the translation field. Accordingly, it becomes an important measure of reforming the higher education in China in order to foster high-level and practical translation/interpretation talents that can meet the demand of the opening and reform to the world as well as of the development of socialist modernization. To this end, many Chinese universities have undertaken the MTI programs to train more qualified translators and interpreters. Geographical and professional features of the MTI education, like those in other majors, will definitely appear in China arising from social development and progress, which means the need of meticulous division of work - translation on law, petroleum project or medical science. This requires the training universities, on the premise of following up the MTI Guidelines published by the Office of the State Council Academic Degrees Committee, actively cultivate high-level, practical and professional translation talents who are qualified for the market needs, based on their own advantages and features and specific curriculum. The MTI program with special features is a new trend of MTI education, which should aim at meeting the urgent need of the national and regional market.

Therefore, under such a background, the MTI training universities of political science and law must combine the market need with their own characteristics and develop their featured programs

\footnotetext{
${ }^{30}$ The author's institution recently hired 6 practice supervisors from Beijing, Xian, Shenzhen and Guangzhou who will regularly guide and supervise the translation/interpretation practice of the 30 MTI candidates (Year 2015), through the internship, temp work or web-assisted supervision, apart from periodical visit and on-site teaching on campus.
} 
based on the teaching personnel and curriculum design. It is an important development direction to continue to develop the MLTI program and cultivate qualified legal translators in China. In the context of "One Belt and One Road" Initiative, the MLTI program should have a clear education philosophy, a featured curriculum, an optimized course system, a group of experienced teaching staff and a set of mature education quality management and control system. Moreover, inter-university and even international exchange, cooperation and experience sharing would help to make improvement in securing the teaching quality in the MTI program. However, overall, they should meet the demand of market need. In this regard, it is both a challenge and a development opportunity to the universities of political science and law in China when exploring multimode of fostering legal translation talents in the context of integration of the production, teaching and research.

This paper is the staged research achievement of the Project Research on Inter-disciplinary Talent Training Model for Legal Translation Program sponsored by China National Committee for Translation \& Interpretation Teaching Guidance (Project No. MTIJZW201606).

\section{References}

Bao, Chuanyun. 2003. Key Considerations in Translator and Interpreter Education. Chinese Translators Journal (Zhongguo Fanyi) 2: 48-50.

Cao, Shu, Han Zhulin, and Liu Ximeng. 2015. Reform the Path of Legal Affairs Translation Teaching in Colleges and Universities. Journal of Jixi University (Jixi Daxue Xuebao) 11: 105-108.

China National Committee for MTI Education. 2014. Name List of the Institutions of Running the MTI Programme. 7 July. Available at http://cnmti.gdufs.edu.cn/info/1017/1095.htm (Accessed 16 October 2016).

China National Committee for MTI Education.2013. Evaluation Index for the Training Institutions of Running the MTI Programme. 26

December.

Available 
at http://cnmti.gdufs.edu.cn/info/1014/1303.htm (Accessed 16 October 2016).

Dai, Weidong, and Wang Xuemei. 2005. Collaborative-inquiry Model in Teaching for Postgraduate of English Major-Definition, Theoretical Basis and Application. Foreign Languages in China (Zhongguo Waiyu) 4: 12-16.

He, Gangqiang. 2007. Skillful and Patient - Three Skills that a Teacher of Translation Should Possess. Foreign Language World (Waiyu Jie) 3: 24-29.

Kong, Lingcui, and Wang Hui. 2011. Cold Thinking of Hot MTI Programs. Foreign Language World (Waiyu Jie) 3: 9-15.

Secretariat of China National Committee for MTI Education. 2012. Conduct Well the MTI Evaluation Work and Promote Health Development of the MTI Education-Interview with Professor He Qixin. Chinese Translators Journal (Zhongguo Fanyi) 2: 52-56.

Shan, Ping. 2016. A General Survey of MTI Education in China: Current Situation, Problems and Suggestions-Taking MTI Education in the Universities in Dalian as a Case. Language Education (Yuyan Jiaoyu) (4)2: 2-7.

Tian, Guoli, Sun Bin, and Rong Jing. 2014. On the Innovation Mechanism in Cultivating Translation Talents Based on the Development of Regional Economy. Hebei Academic Journal (Hebei Xuekan) 34(4): 232-235.

$21^{\text {st }}$ Century. 2009. 25 Institutions of Higher Education Have Been Approved for New Qualification of MTI. 21 ${ }^{\text {st }}$ Century (Yingyu Jiaoyu Zhoukan). July $13 . \quad$ Available at http://paper.i21st.cn/story/53256.html (Accessed 16 October 2016).

Wang, Jun, and Yu Jiayi. 2016. Problems and Countermeasures in the MTI Education. Modern Communication (Xiandai Jiaoji) 4: 226-227.

Wang, Lifei. 2016. Analysis of the Enterprises' Walking out Data on Language Service and Strategies - Reflection on the Training of MTI Talents. Paper of the 2016 Annual Conference of National MTI Degree Education.

Wang, Zhiwei. 2012. Training of Talents of Applied Translation in the USA and Its Implication to MTI in China. Foreign Language World (Waiyu Jie) 4: 52-60. 
Qinglin MA, Xin FU: MLTI Education in China...

Xu, Duo. 2017. On the Dilemma and Countermeasures for Fostering Intellectuals of Legal Translation under the MTI. Foreign Languages in China (Zhongguo Waiyu) 4:14-20.

Zhao, Junfeng. 2018. On the Disciplinary Construction of Legal Translation: Notion and Thinking. Foreign Language Studies (Waiguo Yuyan Wenxue) 2:192.

Zhong, Weihe. 2014. Problems on the Education of the MTI Program in China and Countermeasures. Chinese Translators Journal (Zhongguo Fanyi) 4: 40-44.

Zhuang, Zhixiang. 2007. Construction of Translation Major in China - Problems and Countermeasures (Woguo Fanyi Zhuanye Jianshe - Wenti yu Duice). Shanghai: Shanghai Foreign Language Education Press. 